\title{
Evaluation of the benefits and efficacy of light emitting diode (LED) device with respect to conventional fluorescent tube phototherapy device in neonatal hyper bilurubenimia in near term and full term neonates
}

\author{
Murmu M.C. ${ }^{1}$, Das L. ${ }^{2}$, Suneer C.M. ${ }^{3}$ \\ ${ }^{1}$ Dr. Mangal Charan Murmu, Assistant Professor, ${ }^{2}$ Dr. Leena Das, Associate Professor, ${ }^{3}$ Dr. Suneer C.M., Resident \\ Physician, all authors are affiliated with Department of Pediatrics, S C B Medical College, Cuttack, Odisha, India.
}

Address for Correspondence: Dr. Mangal Charan Murmu, E-mail: mangal74murmu@ yahoo.co.in

\begin{abstract}
Introduction: Neonatal jaundice is a common, in most cases a benign problem in neonates. About $60 \%$ of term and $80 \%$ of preterm babies develop jaundice during the first week of life. About 5-10\% of all newborns need phototherapy for this commonest morbidity in neonatal life. The commonly used light sources are special blue fluorescent tubes, compact fluorescent tubes and halogen spotlights. In recent years a new type of light source light emitting diodes (LED) has been incorporated into phototherapy. Methodology: Hospital based prospective and observational study. The study was done over a period of two years in SNCU, NICU and Newborn ward, department of paediatrics, S.C.B. Medical College, Cuttack from September 2014 to August 2016. Investigation were done in the department of pathology, biochemistry and central laboratory. Results: The duration of phototherapy was shorter in patients who received LED phototherapy than those treated with conventional phototherapy. The children receiving LED phototherapy has less weightloss compared to conventional photo therapy. There is $12 \%$ extra loss of weight during phototherapy in children with conventional phototherapy. Rebound hyperbilirubenimia was more in children treated with LED phototherapy. About $12 \%$ babies developed rebound hyperbilirubenimia in those treated with LED Phototherapy as compared to $8 \%$ of conventional phototherapy. Side effects are more in conventional phototherapy. Conclusion: LED is safe rescue treatment for severe neonatal hyperbilirubenimia and its implementation reduce the failure of phototherapy and need for exchange transfusion.
\end{abstract}

Keywords: Phototherapy, Kernicterus, Hyperbilirubinemia

\section{Introduction}

Hyperbilirubenimia is defined as the increase in serum bilirubin level in circulation. Jaundice attributable to physiological immaturity of neonates to handle increased bilirubin production is termed as physiological jaundice. Visible jaundice usually appears between 24 to 72 hours of life. TSB (Total Serum Bilirubin) levels usually rises in term infants to a peak level of 12 to $15 \mathrm{mg} / \mathrm{dl}$ by 3 Days of life and than fall. In preterm babies, the peak level occurs on the 3 to 7 days of age and TSB can rise over $15 \mathrm{mg} / \mathrm{dl}$.Pathological jaundice is said to be present when TSB concentrations are not in physiological jaundice range, which is

Manuscript received: $18^{\text {th }}$ April 2017

Reviewed: $28^{\text {th }}$ April 2017

Author Corrected: $7^{\text {th }}$ May 2017

Accepted for Publication: $14^{\text {th }}$ May 2017 defined arbitrarily and loosely as more than $5 \mathrm{mg} / \mathrm{dl}$ on first day, $10 \mathrm{mg} / \mathrm{dl}$ on second day and 12-13 mg/dl thereafter in term neonates. Any bilirubin value of $17 \mathrm{mg} / \mathrm{dl}$ or more should be evaluated for the cause and possible intervention, such as phototherapy $[7,8]$. About $60 \%$ of term and $80 \%$ of preterm babies develop jaundice during the first week of life [1,2]. About 5$10 \%$ of all newborns need phototherapy for this commonest morbidity in neonatal life [3]. Premature babies have much higher incidence of neonatal jaundice requiring therapeutic intervention more commonly than the term newborns [4]. Although the outcome for the majority is benign, infaints with untreated, severe hyper bilirubenimia (defined as serum bilirubin level $>20 \mathrm{mg} / \mathrm{dl}$ ) can develop signs of Acute billirubin 
encephalopathy (ABE). Management of hyperbillirubenimia includes detection of at risk neonates, investigating the cause of pathological hyperbillirubenimia, deciding the thresholds for starting and stopping treatment and follow-up of neonates with severe hyperbillirubinemia [5].

Common risk factors for pathological unconjugated jaundice include blood group incompatibility, glucose6-phosphate dehydrogenase enzyme deficiency, prematurity, instrumental delivery and non-optimal breastfeeding. A direct relationship between severe unconjugated hyperbilirubenimia and neurological damage has been demonstrated. Acute bilirubin encephalopathy is caused by the toxic effects of unconjugated bilirubin on the central nervous system.

A morbidity which if untreated, may progress rapidly to advanced manifestations such as opisthotonous and seizures. Intervention such as exchange blood transfusion and phototherapy aim at reducing the serum bilirubin in order to prevent bilirubin brain toxicity [9].Understanding the dose response effect and other factor that influence the way light works to lower the bilirubin levels has led to the effective use of phototherapy and has eliminated the need of exchange transfusion in all most all jaundiced infaints [11]. The efficacy of phototherapy depends upon wavelength irradiance, exposed body surface area, distance of photo therapy and duration of exposure. Intensive phototherapy is provided by use of high levels of irradiance in the 430to $490 \mathrm{~nm}$ band (usually $30 \mu \mathrm{W} / \mathrm{cm}$ $\mathrm{sq} / \mathrm{nm}$ or higher) delivered to as much of infant's body surface area as possible [14].

The commonly used light sources are special blue fluorescent tubes, compact fluorescent tubes and halogen spotlights $[13,14]$. In recent years a new type of light source light emitting diodes (LED) has been incorporated into phototherapy. LEDs are power efficient, portable device with low heat production so that it can be placed very close to the skin of the baby without any apparent untoward effects. They are durable light sources with average life span of 20,000 hours [17]. Blue LEDs have a narrow spectral band of high intensity monochromatic light that overlaps the absorption spectrum of bilirubin [17]. The unique characteristics of LEDs make them attractive light source for an optimal phototherapy unit.

The present study is to evaluate efficacy of LED phototherapy in comparison with conventional phototherapy in the management of neonatal hyperbillirubinemia and to compare its side effects and ability to prevent exchange transfusion, to compare the comfort level of staff during photo therapy.

Aim-To evaluate the benefits and efficacy of light emitting diode (LED) with respect to conventional fluorescent tubes phototherapy device in management of neonatal hyperbilirubinemia in term and near term newborns.

Objectives- To evaluate the benefits of LED phototherapy as compared to conventional photo therapy in decreasing serum total bilirubin level and duration of treatment with unconjugated hyperbilirubinemia during the first 28 days of life.

Sample Size- 200 Newborn babies

Selection of Babies- All the newborn babies who were admitted in the neonatal wards of paediatrics department at S C B Medical College\& SVPPGIP, Cuttack, full filling the inclusion criteria were examined $\&$ investigated in detail and necessary data was noted in a pre-designed Performa.

\section{Inclusion criteria}

1. Gestational age $>35$ weeks

2. Birth weight $>2 \mathrm{~kg}$

3. Post natal age less than/equal to 28 days

\section{Exclusion criteria}

1. Gestational age $<35$ weeks

2. Birth weight $<2 \mathrm{~kg}$

3.Newborns with $\mathrm{ABO}$ or $\mathrm{Rh}$ incompatibility (Pathological jaundice)

4. Neonates without sepsis \& birth asphyxia

5. Babies more than 28 days of life

\section{Materials and Methods}

This study is Hospital based prospective and observational study. The study was done over a period of two years in SNCU, NICU andNewborn wardof department of paediatrics, S.C.B. Medical College, Cuttack from September 2014 to August 2016. Investigation were done in the department of pathology, biochemistry and central laboratory. 
All the babies were appropriate for gestational age (AGA) and with normal finding on physical examination. Babies with normal blood count and peripheral smear, no evidence of blood group isoimmunisation, negative direct coomb test (DCT), normal reticulocyte count and normal enzyme activities are taken for study.

Out of two hundred newborns, 100 newborns are treated with conventional phototherapy (Group 1). were taken by assessing the values with hour specific Bhutani's nomogram. Visible icterus was evaluated by using Kramer's rule. The skin colour of baby was elicited by using Felix Von Luschan skin colour scale. All the neonates were followed till the baby was present in the hospital i.e. recovery or discharged otherwise (LAMA/DAMA/DEATH)

The newborns are placed in open cribs undressed except for diaper and had eyes covered, interrupted only for feeding, cleaning and blood test. In both groups distance of baby from phototherapy unit was matched. Conventional phototherapy was utilised in group 1 at a distance of 40cm. LED device was also kept at distance of $40 \mathrm{~cm}$. The conventional fluorescent phototherapy unit we used is NEOTECH, MEDITRIX phototherapy unit. The LED system is BRILLIANCE LED SYSTEM, D REV PHOENIX Obelis s a, Boulevard General wahs 53,1030 brussels.

The irradiance of phototherapy units at surface are measured at the level of face, xiphoid and knees by photoradiometer.(THOR MULTIESTER MOD3620FANEM BRASIL). Laboratory examinations included total and direct serum bilirubin at the time of enrolment, blood groups of the newborn and the mother, blood test for hemolysis, unusually shaped red cell, or evidence of infection and test for G6PD deficiency.

Venous sampling for serum bilirubin is done at 8, 24 and 48 hours. The values are compared with transcutaneous bilirubin level which is taken using a DRAGER-JM103 transcutaneous bilirubinometer over the covered area. Axillary body temperature was measured every 4 hours.

The present study is an attempt to evaluate the efficacy of LED Phototherapy with respect to conventional phototherapy and the benifits like preventing exchange transfusion, decreasing side effects and its role in management of neonatal hyperbilirubenimia.

\section{Observation}

Table-1: Gestatinal age and sex distribution in our study $(\mathbf{n}=200)$.

\begin{tabular}{|c|c|c|c|}
\hline Gestational age & Boy baby & Girl baby & Total \\
\hline Late pre term & 12 & 20 & 32 \\
\hline Term & 108 & 60 & $\mathbf{2 0 0}$ \\
\hline Total & $\mathbf{1 2 0}$ & $\mathbf{8 0}$ & \\
\hline
\end{tabular}

Out of two hundred newborn $168(84 \%)$ were term and remaining were late preterm as shown in table 1 . Boy baby were $120(60 \%)$ and girl baby were $80(40 \%)$ with a boy to girl ratio $1.5: 1$

Table-2: Postnatal age of presentation to hospital and day of onset of jaundice.

\begin{tabular}{|c|c|c|}
\hline Day of life & Admission ( no of babies) & Onset of jaundice(no of babies ) \\
\hline Less than 24 hours & Nil & $50(25 \%)$ \\
\hline $24-48$ hours & $68(34 \%)$ & $150(75 \%)$ \\
\hline More than 48 hours & $132(66 \%)$ & nil \\
\hline
\end{tabular}

The mean age of presentation to hospital 51.89+/- 4.5 hours with a majority $132(66 \%)$ babies brought to the hospital after 48 hrs of post natal life followed by 68 (43\%) babies admitted between 24-48 hours as shown in table 2. Most of the babies developed jaundice after 48 hours, 150 cases (75\%), 50 cases (25\%) developed jaundice between 24-48 hours. There is no case with jaundice developed less than 24 hours. 
Table -3: Kramer's grading at the time of admission.

\begin{tabular}{|c|c|}
\hline Kramer's stage & number of babies \\
\hline III & 14 \\
\hline Iv & 102 \\
\hline v & 84 \\
\hline Total & 200 \\
\hline
\end{tabular}

At presentation $102(51 \%)$ babies had Kramer stage IV for jaundice followed by 84(42\%) with stage V jaundice and remaining $14(7 \%)$ have stage III jaundice.

Table-4: Demographical, clinical and laboratory characteristics.

\begin{tabular}{|c|c|c|}
\hline Parameter & Conventional group & LED Group \\
\hline Mean gestational age in week & $38.76+/-1.13$ & $38.38+/-1.14$ \\
\hline Gestational age range in week & $35-41$ & $35-41$ \\
\hline Mean weight at initiation of phototherapy in grams & $2772+/-227$ & $2719+/-282$ \\
\hline Mean weight at stoppage $\mathrm{f}$ phototherapy in grams & $2610+/-197$ & $2576+/-276$ \\
\hline Mean weight loss in grams & $161+/-110$ & $142+/-41$ \\
\hline Mean post natal age at admission in hours & $52.22+/-4.8$ & $51.56+/-4.2$ \\
\hline Mean postnatal age at development of jaundice in hours & $52.58+/-5.10$ & $52.84+/-3.74$ \\
\hline Mean time of initiation of phototherapy in hours & $52.58+/-5.10$ & $52.84+/-3.74$ \\
\hline Mean initial bilirubin in $\mathrm{mg} / \mathrm{dl}$ & $17.38+/-1.17$ & $18.88+/-1.04$ \\
\hline Mean biliribin at 8 hour in $\mathrm{mg} / \mathrm{dl}$ & $16.80+/-1.44$ & $15.06+/-1.73$ \\
\hline Mean biliribin at 24 hour in $\mathrm{mg} / \mathrm{dl}$ & $16+/-2.17$ & $14.62+/-1.73$ \\
\hline Mean biliribin at 48 hour in $\mathrm{mg} / \mathrm{dl}$ & $14.88+/-3.99$ & $12.48+/-2.80$ \\
\hline Mean biliribin at stoppage in $\mathrm{mg} / \mathrm{dl}$ & $12.92+/-3.6$ & $12.26+/-2.84$ \\
\hline Mean duration & $60.68+/-16.9$ & $50+/-2.58$ \\
\hline Fall of bilirubin in $\mathrm{mg} \mathrm{dl} / \mathrm{hr}$ & $0.058+/-0.03$ & $0.137+/-0.04$ \\
\hline Relative change in bilirubin at 8 hour $(\% / \mathrm{hr})$ & $0.41+/-0.2$ & $1.2+/-0.5$ \\
\hline Relative change in bilirubin at 48 hour $(\% / \mathrm{hr})$ & $0.29+/-0.3$ & $0.7+/-0.3$ \\
\hline Rebound jaundice in number & 8 & 12 \\
\hline Relative change in bilirubin at 8hour $(\% / \mathrm{hr})$ & 20 & 6 \\
\hline Mean irradiance $(\mu \mathrm{W} / \mathrm{cm}$ square $/ \mathrm{nm})$ & $18.04+/-1.40$ & $36.34+/-1.13$ \\
\hline Side effect in number & 20 & 12 \\
\hline Comfort Likerts scale & $20 \%$ & $80 \%$ \\
\hline
\end{tabular}

As shown the table LED over score conventional florescent phototherapy in each and every respect.

Table-5: Gestational age of study group.

\begin{tabular}{|c|c|c|c|c|c|c|}
\hline $\begin{array}{c}\text { Gestational } \\
\text { age in weeks }\end{array}$ & TYPE & $\mathbf{N}$ & $\begin{array}{c}\text { MEAN } \\
\text { (week) }\end{array}$ & $\begin{array}{c}\text { Std. } \\
\text { deviation }\end{array}$ & $\begin{array}{c}\text { Std. Error } \\
\text { mean }\end{array}$ & t and p value \\
\cline { 2 - 7 } & LED & 100 & 38.38 & 1.14 & 0.101 & $\begin{array}{c}\mathrm{t}=1.67 \\
\mathrm{df}=97.99 \\
\mathrm{p}=0.098\end{array}$ \\
\cline { 2 - 7 } & Conventional & 100 & 38.76 & 1.135 & 0.101 & \\
\hline
\end{tabular}

In this study we allotted 100 newborn babies to LED group with an average gestational age of 38.38+/- 1.14 weeks and 100 to conventional group with average gestational age of $38.76+/-1.135$ weeks. Gestational age is compared by dividing the babies into two groups LED and conventional and independent $t$ test was applied to find out the statistical difference. The test shows gestational age did not have any statistical difference in child with LED and conventional phototheray. 
Table -6: Post natal age of admission.

\begin{tabular}{|c|c|c|c|c|c|c|}
\hline postnatal & Type & N & $\begin{array}{c}\text { Mean } \\
\text { hours }\end{array}$ & Std. deviation & $\begin{array}{c}\text { Std. Error } \\
\text { mean }\end{array}$ & t and p value \\
\hline \multirow{2}{*}{$\begin{array}{c}\text { Age } \\
\text { In hours }\end{array}$} & LED & 100 & 51.56 & 4.200 & 0.594 & $\mathrm{t}=0.726$ \\
\cline { 2 - 6 } & Conventional & 100 & 52.22 & 4.871 & 0.689 & $\begin{array}{c}\mathrm{df}=95.93 \\
\mathrm{p}=0.470\end{array}$ \\
\hline
\end{tabular}

We allotted 100 newborn babies each into LED and Conventional phototherapy group with LED group having mean post natal age of admission $51.56+/-4.20$ hours and conventional group having mean postnatal age of 52.22+/-4.87 hours. Postnatal age was compared in both the groups and the statistical difference was measured by independent $\mathrm{t}$ test. It shows that the postnatal age had no statistical difference in both the age group.

Table-7: Time of initiation, stoppage and duration of phototherapy.

\begin{tabular}{|c|c|c|c|c|}
\hline Time & LED & Conventional & difference & t and p value \\
\hline $\begin{array}{c}\text { Time of initiation } \\
\text { in hours }\end{array}$ & 52.84 & 52.58 & 0.260 & $\mathrm{t}=0.290$ \\
$\mathrm{df}=89.95$ \\
$\mathrm{p}=0.772$
\end{tabular}

There is no statistical difference in the time of phototherapy $(\mathrm{t}=0.290, \mathrm{p}=0.772)$ but there is significant statistical difference in the time of stoppage $(\mathrm{t}=4.091, \mathrm{p}=0.001)$ and duration $(\mathrm{t}=4.313, \mathrm{p}=0.001)$ of phototherapy in both the groups.

Table-8: Fall of bilirubin during phototherapy.

\begin{tabular}{|c|c|c|c|c|c|c|}
\hline Hrs of phototherapy & Type & $\mathbf{N}$ & Mean & Std. deviation & $\begin{array}{l}\text { Std. Error } \\
\text { mean }\end{array}$ & $\begin{array}{l}t \text { and } p \\
\text { value }\end{array}$ \\
\hline \multirow{2}{*}{$\begin{array}{l}\text { Bilirubin at initiation } \\
\qquad(\mathrm{mg} / \mathrm{dl})\end{array}$} & LED & 100 & 18.8 & 1.043 & 0.147 & \multirow{2}{*}{$\begin{aligned} \mathrm{t} & =6.748 \\
\mathrm{df} & =96.614 \\
\mathrm{p} & =0.081\end{aligned}$} \\
\hline & Conventional & 100 & 17.9 & 1.176 & 0.166 & \\
\hline \multirow[t]{2}{*}{ Bilirubin at $8 \mathrm{hrs}(\mathrm{mg} / \mathrm{dl})$} & LED & 100 & 15.06 & 1.038 & 0.147 & \multirow{2}{*}{$\begin{array}{c}\mathrm{t}=1.034 \\
\mathrm{df}=89.01 \\
\mathrm{p}=0.03\end{array}$} \\
\hline & Conventional & 100 & 16.80 & 1.443 & 0.204 & \\
\hline \multirow{2}{*}{$\begin{array}{l}\text { Bilirubin at } 48 \mathrm{hrs} \\
(\mathrm{mg} / \mathrm{dl})\end{array}$} & LED & 100 & 12.48 & 2.808 & 0.397 & \multirow{2}{*}{$\begin{aligned} \mathrm{t} & =3.485 \\
\mathrm{df} & =88.129 \\
\mathrm{p} & =0.001\end{aligned}$} \\
\hline & Conventional & 100 & 14.88 & 3.978 & 0.563 & \\
\hline \multirow{2}{*}{$\begin{array}{l}\text { Bilirubin at stoppage } \\
(\mathrm{mg} / \mathrm{dl})\end{array}$} & LED & 100 & 12.26 & 2.841 & 0.402 & \multirow{2}{*}{$\begin{aligned} \mathrm{t} & =4.088 \\
\mathrm{df} & =92.779 \\
\mathrm{p} & =0.1\end{aligned}$} \\
\hline & Conventional & 100 & 12.92 & 3.619 & 0.512 & \\
\hline \multirow{2}{*}{$\begin{array}{l}\text { Fall of bilirubin } \\
\qquad(\mathrm{mg} / \mathrm{dl} / \mathrm{hr})\end{array}$} & LED & 100 & 0.137160 & 0.045698 & 0.006462 & \multirow{2}{*}{$\begin{aligned} \mathrm{t} & =9.713 \\
\mathrm{df} & =91.725 \\
\mathrm{P} & =0.002\end{aligned}$} \\
\hline & Conventional & 100 & 0.058122 & 0.034963 & 0.004944 & \\
\hline
\end{tabular}


The mean bilirubin at initiation of phototherapy is $18.8+/-1.04 \mathrm{mg} / \mathrm{dl}$ in LED group and $17.9+/-1.17 \mathrm{mg} / \mathrm{dl} \mathrm{in}$ conventional group and bilirubin level at 8 hours is $15.06+/-1.04 \mathrm{mg} / \mathrm{dl}$ in LED group and $16.80+/-1.44 \mathrm{mg} / \mathrm{dl}$ in conventional group, while the bilirubin at 48 hours is $12.48+/-2.80 \mathrm{mg} / \mathrm{dl}$ in LED group and $14.88+/-3.97 \mathrm{mg} / \mathrm{dl} \mathrm{in}$ conventional group. The bilirubin at stoppage is $12.26+/-2.841 \mathrm{mg} / \mathrm{dl}$ and $12.92+/-3.619 \mathrm{mg} / \mathrm{dl}$ in both groups. The fall of bilirubin is $0.1371+/-0.0456 \mathrm{mg} / \mathrm{dl} / \mathrm{hour}$ in LED group and $0.0581+/-0.004 \mathrm{mg} / \mathrm{dl} / \mathrm{hr}$ in conventional group. There is no significance difference in the case of bilirubin at initiation and bilirubin at stoppage since the $\mathrm{p}$ value is more than 0.05 as seen in the bilirubin at 8,48 hours;and the fall of bilirubin shows a definite statistical difference between LED and conventional group ( $\mathrm{p}$ value $<0.05)$.

Table-9: Irradiance of phototherapy.

\begin{tabular}{|c|c|c|c|c|c|c|}
\hline \multirow{3}{*}{$\begin{array}{c}\text { Irradiance in } \\
\mu W / \mathrm{cm} \text { square } \\
\text { /nm }\end{array}$} & Type & $\mathbf{N}$ & Mean & Std. deviation & $\begin{array}{c}\text { Std. Error } \\
\text { mean }\end{array}$ & $\begin{array}{c}\text { T and } p \\
\text { value }\end{array}$ \\
\hline & LED & 100 & 36.3460 & 1.13573 & 0.1606 & \multirow{2}{*}{$\begin{array}{c}\mathrm{t}=71.695 \\
\mathrm{df}=93.914 \\
\mathrm{p}=0.001\end{array}$} \\
\hline & CONVENTIONAL & 100 & 18.0400 & 1.40349 & 0.1984 & \\
\hline
\end{tabular}

The mean iradiance of LED phototherapy unit is $36.35+/-1.13$ where as in conventional fluorescent phototherapy unit is by using THOR 3620 Flux meter. Comparing the irradiance of LED phototherapy unit and conventional fluorescence tube phototherapy unit there is a significant statistical difference $(\mathrm{t}=71.69, \mathrm{p}=0.0001)$

Table-10: Weight loss during phototherapy.

\begin{tabular}{|c|c|c|c|c|c|c|}
\hline & Type & $\mathbf{N}$ & Mean & $\begin{array}{c}\text { Std. } \\
\text { deviation }\end{array}$ & $\begin{array}{l}\text { Std. Error } \\
\text { mean }\end{array}$ & $\begin{array}{l}t \text { and } p \\
\text { value }\end{array}$ \\
\hline \multirow{2}{*}{$\begin{array}{l}\text { Weight at initiation in } \\
\text { grams }\end{array}$} & LED & 100 & 2719 & 282.642 & 39.972 & \multirow{2}{*}{$\begin{array}{l}\mathrm{t}=1.033 \\
\mathrm{df}=93.75 \\
\mathrm{p}=0.304\end{array}$} \\
\hline & Conventional & 100 & 2772 & 227.713 & 32.203 & \\
\hline \multirow{2}{*}{$\begin{array}{c}\text { Weight at stoppage in } \\
\text { grams }\end{array}$} & LED & 100 & 2576 & 276.642 & 39.123 & \multirow{2}{*}{$\begin{aligned} \mathrm{t} & =0.750 \\
\mathrm{df} & =92.618 \\
\mathrm{p} & =0.478\end{aligned}$} \\
\hline & Conventional & 100 & 2611 & 197.370 & 27.912 & \\
\hline \multirow[t]{2}{*}{ Weight loss in grams } & LED & 100 & 142 & 41.699 & 5.897 & \multirow{2}{*}{$\begin{array}{c}\mathrm{t}=1.069 \\
\mathrm{df}=90.658 \\
\mathrm{p}=0.06\end{array}$} \\
\hline & Conventional & 100 & 161 & 110.583 & 15.639 & \\
\hline
\end{tabular}

The weight at initiation in LED group and conventional group is $2719+/-282.64$ and $2772+/-227.71 \mathrm{~g}$ respectively. The weight at stoppage is $2576+/-276.64 \mathrm{~g}$ and $2611+/-197.37 \mathrm{~g}$ in both groups. Hence the mean weight loss is $141+/-1.699 \mathrm{~g}$ and $161+/-110.583 \mathrm{~g}$ in both group respectively. There is no significant difference regarding the weight of the babies during initiation and stoppage of phototherapy groups $(\mathrm{t}=1.033$ and $\mathrm{p}=0.304, \mathrm{t}=0.750$ and $\mathrm{p}=0.06)$. Even the weight loss is more during conventional phototherapy, there is no definite statistical difference.

Table-11: Rebound hyperbilirubinemia.

\begin{tabular}{|c|c|c|c|}
\hline Type & N & Rebound & p and t values \\
\hline LED & 100 & 12 & $\mathrm{t}=0.887$ \\
$\mathrm{df}=94.30$ \\
$\mathrm{p}=0.38$ \\
\hline
\end{tabular}

Out of 100 babies treated with LED Phototherapy 12 babies have rebound hyperbilirubinimia as compared to 8 in conventional phototherapy. There is significant between both group since the $\mathrm{p}$ value is 0.38 . 
Table-12: Failure of Phototherapy.

\begin{tabular}{|c|c|c|c|c|}
\hline TYPE & $\mathbf{N}$ & Failure & & p and t value \\
\hline LED & 100 & Exchange transfusion & 0 & $\mathrm{t}=2.107$ \\
& & DSPT & 6 & $\mathrm{df}=79.729$ \\
\cline { 3 - 4 } & & $\mathrm{p}=.003$ & \\
\cline { 1 - 3 } Conventional & 100 & Exchange transfusion & 16 & \\
\cline { 3 - 4 } & & DSPT & & \\
\hline
\end{tabular}

There is total number of 20 failure in conventional phototherapy, sixteen of them going for DSPT and four out of them going for exchange transfusion. In LED group there is only six failures all going for DSPT. There is a significant difference in failure of phototherapy between both group.

Table-13: Side effect \& Staff and parental comfort during phototherapy.

\begin{tabular}{|c|c|c|c|c|c|}
\hline \multirow[t]{2}{*}{ Type } & \multirow[t]{2}{*}{$\mathbf{N}$} & \multirow[t]{2}{*}{ Side effect } & \multirow{2}{*}{$\begin{array}{l}t \text { and } p \\
\text { value }\end{array}$} & $\mathrm{N}=\mathbf{2 0 0}$ & \multirow{2}{*}{$\begin{array}{l}t \text { and } p \\
\text { value }\end{array}$} \\
\hline & & & & $\begin{array}{c}\text { Staff and parental } \\
\text { comfort }\end{array}$ & \\
\hline \multirow[t]{5}{*}{ LED } & \multirow[t]{5}{*}{100} & Hyperthermia 0 & \multirow[t]{5}{*}{$\mathrm{t}=1.488$} & \multirow[t]{5}{*}{160} & \multirow{10}{*}{$\begin{aligned} \mathrm{t} & =2.578 \\
\mathrm{df} & =76.658 \\
\mathrm{p} & =0.012\end{aligned}$} \\
\hline & & Hypothermia 2 & & & \\
\hline & & Burns and rash 4 & & & \\
\hline & & Dehydration 0 & & & \\
\hline & & $\begin{array}{c}\text { Irritability \& crying } \\
6\end{array}$ & & & \\
\hline \multirow[t]{5}{*}{ Conventional } & \multirow[t]{5}{*}{100} & Hyperthermia 4 & & \multirow[t]{5}{*}{40} & \\
\hline & & Hypothermia 0 & & & \\
\hline & & Burns and rash 5 & & & \\
\hline & & Dehydration 1 & & & \\
\hline & & $\begin{array}{l}\text { Irritability \& crying } \\
10\end{array}$ & & & \\
\hline
\end{tabular}

The LED group total of about twelve babies developed some side effect while in conventional group about twenty babies developed side effects showing $\mathrm{p}$ value 0.140 . so there is no significant statistical difference. In LED group there is no case of hyperthermia, while 2 babies developed hypothermia (2\%). There are no case of dehydration, while four babies developed rash (4\%). In conventional group they developed four cases of hyperthermia (4\%), five cases of rashes $(5 \%)$ and one case of dehydration (1\%), irritability and excessive crying is more in conventional (10\%) than LED (6\%).

Out of total 200 staff (nursingstaff and doctors) 160 favoured LED phototherapy. Here we got the p value 0.012 and is statistically significant.

\section{Discussion}

Out of 200 newborns included in our study, 68(84\%) babies were term and remaining $32(16 \%)$ babies were late preterm with baby boy being $120(60 \%)$ and girl baby $80(40 \%)$ and M:F ratio $1.5: 1$ as shown in table 1 . This might not be true as study includes only term and late pre term babies. Recent review by Cochrane includes both term and preterm babies, which is different from our study. The study conducted by Majid
Mohammadizadeh [21]in Iran in 2012 includes only preterm neonate. The average age of gestation in babies treated with LED phototherapy is $38.38+/-1.14$ weeks and conventional group is $38.76+/-1.13$ weeks. Similar results were observed by other authors [28,29]. Table 2 shows the mean age of presentation to the hospital $51.89+/-4.5$ hours with majority $132(66 \%)$ babies brought to hospital after48 hours of post natal life 
followed by $68(38 \%)$ babies between $24-48$ hours[10,] The average post natal age of presentation in LED group is $51.56+/-4.871$ hours, a study by Martin 2007 have similar results $[19,20]$. There is significant difference in time of stoppage $(\mathrm{t}=4.091, \mathrm{p}=0.002)$ and duration of photo therapy ( $\mathrm{t}=4.431, \mathrm{p}=0.001)$ while comparing LED with conventional group as shown in table -10. The study shows duration of phototherapy with LED is much lower. Similar results were observed by other authors $[19,21,22,26]$.

The mean bilirubin at the time of initiation and stoppage was almost similar in two groups, there by indicating that uniform guidelines was followed for starting and stopping of phototherapy. This is in accordance with Kumar et al [28]. LED phototherapy might be useful in treating severe hyperbilirubenimia and there by preventing its complications $[19,20,23,24]$. The average irradiance of LED in our study is $36.34+/-1.35 \mu \mathrm{W} / \mathrm{cm}$ square /nm which was below reported level according to Tan et al [27].

The rebound hyperbilirubinemia is more in LED as compared to conventional, this is against Belma et al[23], Seidman 2003[23]. The weight loss during phototherapy is more in conventional group (161+/$110 \mathrm{gms})$ than LED group $(142+/-41.699 \mathrm{gms})$, this is comparable with Kumar et al 2009[28], uras et al 2009[29]. The study shows that LED phototherapy re more efficient in preventing failure of phototherapy and exchange transfusion, which is same as study done by kumar et al 2010[19] and martins 2007[21]. Uras et al 2009 studied that there were no failure of phototherapy in both LED and conventional group [29]. In our study, in LED group 12 percent children developed any type of side effect against a 20 percent of side effects in babies treated with conventional phototherapy, it is similar to study conducted by Kumar 2010[19] and Martins [21]. In our study which is Likert scale study, out of 200 newborn babies treated with phototherapy about $80 \%$ show more comfort with LED phototherapy while only $20 \%$ opts for conventional phototherapy. It shows a definite statistical difference since more opting for LED phototherapy [ $\mathrm{p}=0.012]$. The study is similar with study done by Seidman et al $[23,24]$.

\section{Conclusion}

Jaundice usually becomes clinically apparent to parents by zone IV and hence need immediate treatment to prevent kernicterus. This can be achieved by institution of proper proper phototherapy more device. LED phototherapy is more efficacious in bringing down the serum bilirubin level. The rate of fall of bilirubin is more with LED phototherapy unit than conventional fluorescent tube phototherapy unit. The maximum fall of billirubin is during initial phase of phototherapy. LED Phototherapy unit have twice the irradiance of conventional phototherapy unit. LED is safe rescue treatment for severe neonatal hyperbilirubenimia and its implementation reduce the failure of phototherapy and need of exchange transfusion.

LED phototherapy device has caused less frequent side effects and there was no acute severe side effects. It produces less heat and dehydration so can be placed very close to the newborn. Moreover LED phototherapy unit provide more nursing comfort as compared to the conventional phototherapy unit. Only draw back with of LED with our study it causes rebound jaundice. Hence LED could be a resourceful technique in view of its efficacy and least side effects and cost effectiveness.

\section{Abbreviations}

ABE: Acute bilirubin encephalopathy, NIND: Neurological induced neurological dysfunction, C F T: Compact fluorescent tube, DSPT: Double surface phototherapy, g/dl: gram per deci liter, i.e.: that is, LED: light emitting Diode, Kg: kilogram, LAMA: Left against medical advice, $\mathbf{N}$ : Number of cases/observation, NNHB: Neonatal hyper bilirubinemia, S: Serum, T S B: Total serum bilirubin, $\%$ : percentage, $\&$ : and, $\boldsymbol{\mu m o l} / \mathbf{L}$ : Micro mol per litre, $\boldsymbol{\mu W} / \mathbf{c m}$ square /nm: micro watt per centimetre square per nanometer.

Funding: Nil, Conflict of interest: None initiated, Perission from IRB: Yes

\section{References}

1. Rishikes Thakre. Neonatal hyperbilirubenimia. In IAP Textbook of paediatrics, $5^{\text {th }}$ edition, print: newdelhi, ISBN: 978-93-5025-945-0. jaypee brothers medical publishers, ch2,72013 page 41-44.

2. N Ambalavanan, W A Carlo. kliegman, Stanton, St. Geme et al jaundice and hyperbillirubenimia in newborn, nelson text book of paediatrics $19^{\text {th }} \mathrm{ed}$, print newdelhi ISBN : 9781437707557, Saunders-Elsevier publication 2012 reprint ch 96.3 pages 603-12.

3. Kivlahan C, James EJ. The natural history of neonatal jaundice. Pediatrics.1984 Sep;74(3):364-70. 
4. Narang A, Kumar P, Kumar R. Neonatal jaundice in very low birth weightbabies. Indian J Pediatr. 2001 Apr;68(4):307-9.

5. NNF clinical practice guidelines. Management of Neonatal hyperbilirubenimia 2012 page 139154.

6. Madan A, Mac Mohan JR, Stevenson DK. Neonatal Hyperbilirubinemia. In Taeush HW, Ballard RA, Gleason CA, eds. Avery's Diseases of the Newborn, 8th ed. Philadelphia; WB Saunders, 12261256.

7. Maisels MJ, Gifford K. Normalserumbilirubinlevels in the newborn and the effect of breast-feeding. Pediatrics. 1986 Nov;78(5):837-43.

8. Rennie J, Burman-Roy S. Murphy MS; Guieline development group. Neonatal jaundice: summary of NICE guidance BMJ 2010 may 19;340:c2409. dio10. 1136/bmj.c2409

9. Juretschke LJ. Kernicterus: still a concern. Neonatal Netw. 2005 Mar-Apr;24(2):7-19.

10. Bhutani VK, Johnson LH, Keren R. Diagnosis and management of hyperbilirubinemia in the term neonate: for a safer first week. Pediatr Clin North Am. 2004 Aug; 51(4):843-61, vii.

11. McDonagh AF. Phototherapy: from ancient Egypt to the new millennium. J Perinatol. 2001 Dec;21 Suppl $1: S 7-S 12$.

12. Ennever JF. Bluelight, greenlight, whitelight, morelight: treatment of neonatal jaundice. Clin Perinatol. 1990 Jun;17(2):467-81.

13. Maisels MJ. Phototherapy--traditional and nontraditional. J Perinatol. 2001 Dec;21 Suppl 1:S93-7; discussion S104-7.

14. American academy of paediatrics: management of hyperbilirubinemia in the newborn infant 35 or more weeks of gestation. Pediatrics 2004; $297-$ 316.

15. Mills JF, Tudehope D,Fibroptic phototherapy for neonatal Jaundice. Cochrane database of systematic revievers2001, issue. Art No:CD002060.D01:10.1002/ 14651858.CD002060.
16. Tan KL. Efficacy of fluorescent daylight, blue, and greenlamps in the management of nonhemolytic hyperbilirubinemia. J Pediatr. 1989 Jan;114(1):132-7.

17. Vreman HJ, Wong RJ, Stevenson DK, Route RK, Reader SD, Fejer MM, Gale R, Seidman DS. Lightemittingdiodes: a novellightsource for phototherapy. Pediatr Res. 1998 Nov;44(5):804-9.

18. Bertini g, Perugi S, Elia S, Pratesi S, Dani S, Rubaltelli FF. Transepidermal water loss and cerebral heamodynamics in preterm infants; Conventional versus LED phototherapy. European journal of paediatrics 2008;167(1):37-42.

19. Kumar P, Murki S, Malik GK, Chawla D, Deorari AK, Karthi N, Subramanian S, Sravanthi J, Gaddam P, Singh SN. Lightemittingdiodesver- suscompact fluorescenttubes for phototherapy in neonatal jaundice: a multicenterrandomized controlled trial. Indian Pediatr. 2010 Feb;47(2):131-7. Epub 2009 May 20.

20. Maisels MJ, Kring EA, DeRidder J. Randomized controlledtrial of light-emittingdiodephototherapy. J Perinatol. 2007 Sep;27(9):565-7. Epub 2007 Jun 28.

21. Majid Mohammadizadeh, Fereshteh Kadkhodaei Eliadarani, Zohreh Badiei, Is the light-emitting diode a be tter light source than fluorescent tube for phototherapy of neonatal jaundice in preterm infants? Advanced Biomedical Research 2012, 1: 51

22. Martins BM, de Carvalho M, Moreira ME, Lopes JM. Efficacy of new microprocessed phototherapy system with five high intensity light emitting diodes (Super LED). J Pediatr (Rio J). 2007 May-Jun;83(3): 253-8.

23. Seidman DS, Moise J, Ergaz Z, Laor A, Vreman HJ, Stevenson DK, Gale R. A newbluelight-emitting phototherapydevice: a prospective randomized controlled study. J Pediatr. 2000 Jun;136(6):771-4.

24. Seidman DS, Moise J, Ergaz Z, Laor A, Vreman HJ, Stevenson DK, Gale R. A prospective randomized controlledstudy of phototherapy using blue and bluegreenlight-emitting devices, and conventionalhalogenquartzphototherapy. J Perinatol. 2003 Mar; 23(2):123-7.

25. Phyllis A Dennary, Daniel S Siedman, David K Stevenson. Neonatal hyperbilirubinemia. New England journal of Medicine Feb 2001;344(8);581-589. 
Original Research Article

26. Dani C, Martelli E, Reali MF, et al . Fiberoptic and conventional phototherapy effects on the skin of premature infants . J Pediatr 2001;138:438-40

27. Belma Saygli Karrogoi, Omer Erdeve; Efficacy of LED Phototherapy in comparison with conventional phototherapy in neonatal jaundice, journal of Ankara university faculty medicine 2007;60(1);30-32

28. Tan KL. The pattern of bilirubin response to phototherapy for neonatal hyperbilirubinaemia. Pediatr Res. 1982 Aug;16(8):670-4.
29. Kumar et al 2009. Light emitting diodes versus compact fluorescent tubes for phototherapy in neonatal jaundice:A multi center randomised controlled trial. Light source of phototherapy:volume47pg132-136.

30. Nurdan Uras, Ahmet Karadag; Comparision of light emitting diode phototherapy and double standard conventional phototherapy for non heamolytic neonatal bilirubinemia. Turk J Med Sci. 2009;39(3):337-341.

31. Zohreh Badiee, Majid Mohammadizadeh, Masih Shamee Diagnostic usefulness of transcutaneous bilirubinometry in very preterm newborns Int $\mathbf{J}$ Prev Med 2012;4:262-5.

\section{How to cite this article?}

Murmu M.C, Das L, Suneer C.M. Evaluation of the benefits and efficacy of light emitting diode (LED) device with respect to conventional fluorescent tube phototherapy device in neonatal hyper bilurubenimia in near term and full term neonates. J PediatrRes.2017;4(05):333-342.doi:10. 17511/ijpr.2017.i05.08 